\title{
Transient intussusception: rare cause of abdominal pain in cystic fibrosis
}

\author{
Suheil Artul, ${ }^{1,2}$ Faozi Artoul, ${ }^{3}$ George Habib, ${ }^{4}$ Nabil Abboud ${ }^{5}$
}

${ }^{1}$ Department of Radiology, Nazareth Hospital, Nazareth, Israel

${ }^{2}$ Faculty Medicine in the Galilee, Bar-Ilan University, Safed Israel, Maghar, Israel

${ }^{3}$ Department of Nuclear Medicine, Meir Hospital, Maghar, Israel

${ }^{4}$ Department of Medicine, Nazareth Hospital, Nazareth, Israel

${ }^{5}$ Department of Surgery, Nazareth Hospital, Nazareth, Israel

\section{Correspondence to}

Dr Suheil Artul, suheil_artul@hotmail.com
CrossMark

\footnotetext{
To cite: Artul S, Artoul F, Habib G, et al. BMJ Case Rep Published online:

[please include Day Month

Year] doi:10.1136/bcr-2013-

201259
}

\section{DESCRIPTION}

A 26-year-old man with history of cystic fibrosis, presented to the emergency department with a 2-day history of abdominal pain, nausea and vomiting. The patient did not have a history of abdominal surgery.

On presentation the patient was afebrile and normotensive. Abdominal examination revealed tenderness in the mid-abdomen and no rebound. Laboratory tests showed slight leucocytosis and normal level of amylase. Abdominal plain radiograph showed gaseous distention of multiple small bowel loops. Contrast CT of the abdomen showed total fatty replacement of the pancreas (figure 1, white arrows), dilated small bowel loops up to $4.5 \mathrm{~cm}$ in diameter (figure 2, red arrows) and a 'solid mass' of $6 \mathrm{~cm}$ in long axis 'cobra head sign' (figure 2, black arrows) indicating ileo-ileal intussusceptions, without any sign of bowel wall suffering such as air or oedema of the involved loop. The patient was treated conservatively and the intussusception resolved spontaneously without any manoeuvre with good clinical outcome.

Cystic fibrosis is the most common lethal autosomal recessive disease in white populations. ${ }^{1}$ The abdominal manifestations are now seen throughout childhood, from infancy to adolescence. The child might present in the neonatal period with meconium ileus or its attendant complications. ${ }^{2}$ The older patients might present with distal intestinal obstruction syndrome or colonic stricture secondary to high doses of pancreatic enzyme replacement.

Intussusceptions in adults are generally very rare in cystic fibrosis. Only 10 cases have been reported

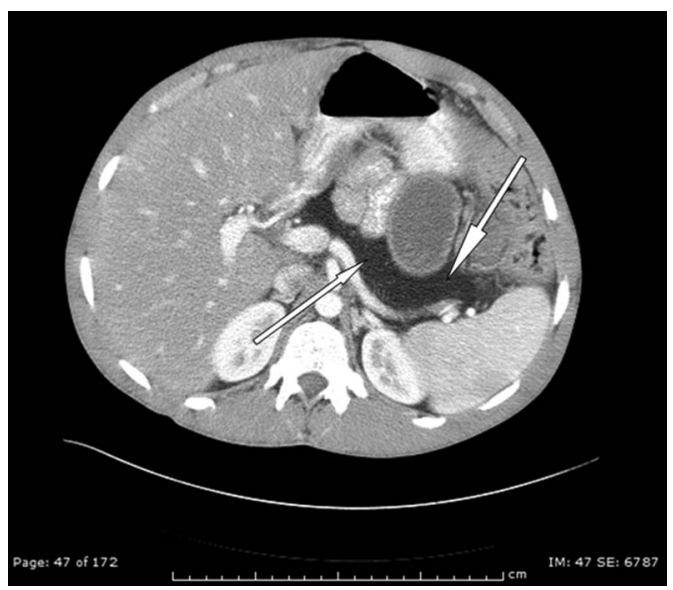

Figure 1 Contrast-enhanced CT of the abdomen showing total fatty replacement of the pancreas (white arrows).

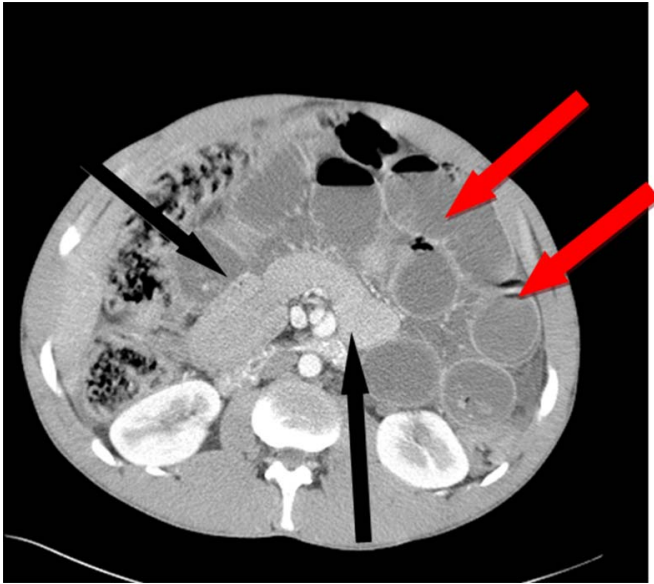

Figure 2 Contrast-enhanced CT of the abdomen showing dilated small bowel loops up to $4.5 \mathrm{~cm}$ in diameter (red arrows), a 'solid mass' of $6 \mathrm{~cm}$ in long axis 'cobra head sign' (black arrows) indicating ileo-ileal intussusception.

to date, 6 of them by Nash et al. ${ }^{3}$ Unlike our case, in all of these published cases were needed surgical reduction.

\section{Learning points}

Adult' intussusception in cystic fibrosis is a very rare cause of abdominal pain.

- CT offers unique information about organ involvement and complications of cystic fibrosis such as intussusception.

- In cystic fibrosis in adults, intussusceptions can be transients and can resolve spontaneously.

Contributors SA wrote the first draft; FA, GH and NA revised and approved the final manuscript.

\section{Competing interests None.}

Patient consent Obtained.

Provenance and peer review Not commissioned; externally peer reviewed.

\section{REFERENCES}

1 Agrons GA, Corse WR, Markowitz RI, et al. 1 Gastrointestinal manifestations of cystic fibrosis. Radiographics 1996;16:871-93.

2 Chaudry G, Navarro OM, Levine DS, et al. Abdominal manifestations of cystic fibrosis in children. Pediatr Radiol 2006;36:233-40.

3 Nash EF, Stephenson A, Helm EJ, et al. Intussusception in adults with cystic fibrosis: a case series with review of the literature. Dig Dis Sci 2011;56:3695-700. 
Copyright 2013 BMJ Publishing Group. All rights reserved. For permission to reuse any of this content visit http://group.bmj.com/group/rights-licensing/permissions.

BMJ Case Report Fellows may re-use this article for personal use and teaching without any further permission.

Become a Fellow of BMJ Case Reports today and you can:

- Submit as many cases as you like

- Enjoy fast sympathetic peer review and rapid publication of accepted articles

- Access all the published articles

- Re-use any of the published material for personal use and teaching without further permission

For information on Institutional Fellowships contact consortiasales@bmjgroup.com

Visit casereports.bmj.com for more articles like this and to become a Fellow 